\title{
PENGARUH PENDAPATAN TRANSFER DAN SILPA TERHADAP BELANJA MODAL DI KABUPATEN MAMBERAMO TENGAH
}

\author{
Abstract \\ Efendi Jikwa ${ }^{1}$ \\ jurnalmkd@gmail.com \\ Agustinus Salle ${ }^{2}$ \\ agustinussalle@gmail.com \\ Paulus K. Allo Layuk ${ }^{3}$
}

\begin{abstract}
This study attempts to know whether income transfers and remaining budget (SILPA) have positive impact on capital expenditure in Mamberamo Tengah Regency. Methods used in this research to cultivate and analyzed data and information using a qualitative approach (descriptive) and quantitative. Technique of analysis in this research consisting of descriptive analysis and statistical analysis. The value of influence done by estimating the coefficients using the concept of ordinary least square (OLS). The results show that: (a) based on the qualitative approach through a method of linear seen that the transfer of the central government through a source of share funds (DBH), general allocation funds (DAU), special allocation funds (DAK) and special autonomy (Otsus) have the proportion of capital spending influence, this can be seen from the coefficients above all having a positive sign. Sources of share funds $(D B H)$ has an influence that was dominant compared with other sources of funds, $(b)$ through the estimation results of the regression coefficient obtained that SILPA affects capital spending in a positive way, this is supported with a value of a coefficient at 83,9 percent (marked positive).
\end{abstract}

Keyword: APBD, DBH, DAU, DAK, OTSUS, SiLPA, capital expenditure, balancing funds

\section{PENDAHULUAN}

Dalam era desentralisasi fiskal diharapkan terjadinya pelayanan di berbagai sektor terutama sektor publik. Peningkatan pelayanan publik ini diharapkan meningkatkan daya tarik bagi investor untuk membuka usaha di daerah. Harapan ini tentunya dapat terwujud apabila ada upaya serius (Pemerintah) dengan memberikan berbagai fasilitas pendukung (investasi). Konsekuensinya, pemerintah perlu untuk memberikan alokasi belanja yang lebih besar untuk tujuan ini. Desentraliasi fiskal di satu sisi memberikan kewenangan yang lebih besar dalam pengelolaan daerah, tetapi disisi lain memunculkan persoalan baru, dikarenakan tingkat kesiapan fiskal daerah yang berbeda-beda. Penelitian yang dilakukan Adi (2005) menunjukan terjadi disparitas pertumbuhan ekonomi yang cukup tinggi antar daerah (kabupaten dan kota) dalam pelaksanaan desentralisasi fiskal.

\footnotetext{
1 Alumni Mahasiswa Magister Keuangan Daerah Universitas Cenderawasih

2 Staf Dosen Jurusan IImu Akuntansi Fakultas Ekonomi \& Bisnis Universitas Cenderawasih

${ }^{3}$ Staf Dosen Jurusan IImu Akuntansi Fakultas Ekonomi \& Bisnis Universitas Cenderawasih
} 
Dalam Anggaran Pendapatan dan Belanja Daerah (APBD), Anggaran Sektor Publik Pemerintah Daerah sebenarnya merupakan output pengalokasian sumberdaya dan pengalokasian sumberdaya merupakan permasalahan yang mendasar dalam penganggaran sektor publik. Keterbatasan sumberdaya sebagai akar masalah utama dalam pengalokasian anggaran sektor publik dapat diatasi dengan pendekatan ilmu ekonomi melalui berbagai teori. Tuntutan untuk mengubah struktur belanja menjadi semakin kuat, khususnya pada daerah-daerah yang mengalami kapasitas fiskal rendah (Halim, 2001).

Untuk mengatasi ketimpangan fiskal dan adanya kebutuhan pendanaan daerah yang cukup besar, pemerintah memberikan dana perimbangan dan salah satu komponen dana ini yang memberikan kontribusi terbesar adalah Dana Alokasi Umum (2005). Dalam beberapa tahun berjalan, proporsi Dana Alokasi Umum (DAU) terhadap penerimaan daerah masih tertinggi dibandingkan dengan penerimaan daerah yang lain, termasuk Pendapatan Asli Daerah (Adi, 2006). Hal ini menunjukkan masih tingginya ketergantungan pemerintah daerah terhadap pasokan dana dari pemerintah pusat ini, Namun demikian, dalam jangka panjang ketergantungan semacam ini harus menjadi semakin kecil. Berbagai investasi yang diberlakukan pemerintah diharapkan memberikan hasil yang positif yang tercermin dalam Peningkatan Pendapatan Asli Daerah (PAD).

Kebijakan otonomi daerah merupakan pendelegasian kewenangan yang disertai dengan penyerahan dan pengalihan pendanaan, sarana dan prasarana dan Sumber Daya Manusia (SDM) dalam kerangka desentralisasi fiskal. Dalam menghadapi desentralisasi fiskal menunjukan bahwa potensi fiskal pemerintah daerah satu dengan daerah yang lain bisa jadi sangat beragam. Perbedaan ini pada gilirannya dapat menghasilkan pertumbuhan ekonomi yang beragam pula. Hasil penelitian yang dilakukan Oates (1995), Lin dan Liu (2000) dalam Darwanto (2007) menunjukan desentralisasi fiskal memberikan dampak yang sangat berarti bagi pertumbuhan ekonomi daerah dan membuktikan adanya hubungan yang positif dan signifikan. Sedangkan penelitian Darwanto (2007) menunjukkan bahwa pertumbuhan ekonomi memiliki korelasi positif namun tidak signifikan terhadap anggaran belanja modal. Dengan demikian bahwa desentralisasi memberikan dampak yang positif terhadap pertumbuhan ekonomi dengan mengalokasikan secara lebih efisien berbagai potensi lokal untuk kepentingan layanan publik.

Pendapatan Asli Daerah adalah Pendapatan Asli Daerah yang terdiri dari hasil pajak daerah, retribusi daerah, pendapatan dari laba perusahaan daerah dan lain-lain pendapatan asli daerah yang sah. Menurut Mardiasmo (2002) saat ini masih banyak masalah yang dihadapi pemerintah daerah terkait dengan upaya 
meningkatkan penerimaan daerah. Keterbatasan infrastruktur seperti sarana dan prasarana yang tidak mendukung untuk investasi menimbulkan pertanyaan bagaimana sebenarnya Alokasi Pendapatan Asli Daerah terhadap anggaran belanja modal, apakah karena Pendapatan Asli Daerah yang rendah atau alokasi yang kurang tepat?.

Abdullah dan Halim (2004) menemukan bahwa sumber pendapatan daerah berupa Pendapatan Asli Daerah dan Perimbangan berpengaruh terhadap belanja daerah secara keseluruhan. Meskipun proporsi PAD maksimal hanya sebesar $10 \%$ dari total pendapatan daerah, kontribusinya terhadap pengalokasian anggaran cukup besar, terutama bila dikaitkan dengan kepentingan politis (Abdullah, 2004).

Menurut Setiaji (2005) perbedaan pertumbuhan PAD tidak diikuti dengan kenaikan share (kontribusi) PAD terhadap anggaran belanja modal dan peningkatan PAD tidak sebanding dengan peningkatan total belanja mereka.

Berdasarkan penelitian empiris yang dilakukan oleh Holtz-Eakin et.al., (1985) dalam Darwanto (2007) menyatakan bahwa terdapat keterkaitan sangat erat antara transfer dari pemerintah pusat dengan belanja pemerintah daerah. Secara spesifik mereka menegaskan bahwa variable-variabel kebijakan pemerintah daerah dalam jangka pendek disesuaikan (adjusted) dengan transfer yang diterima, sehingga memungkinkan terjadinya respon yang non linier dan asymmetric.

Konsekuensi akibat penyerahan kewenangan pemerintah pusat kepada pemerintah daerah mengakibatkan perlunya perimbangan keuangan antara pemerintah pusat dan daerah yang menyebabkan terjadinya transfer yang cukup signifikan di dalam APBN dari pemerintah pusat ke pemerintah daerah, dan pemerintah daerah secara leluasa dapat menggunakan dana tersebut untuk memberi pelayanan yang lebih baik kepada masyarakat atau untuk keperluan lain yang mungkin tidak penting. Dengan adanya transfer dana dari pusat ini diharapkan pemerintah daerah bisa lebih mengalokasikan PAD yang didapatnya untuk membiayai belanja modal di daerahnya.

Dana transfer dari pemerintah pusat ke pemerintah daerah selain DAU adalah Dana Alokasi Khusus (DAK) yaitu dana yang bersumber dari pendapatan APBN yang dialokasikan kepada daerah tertentu dengan tujuan untuk membantu mendanai kegiatan khusus yang merupakan urusan daerah dan sesuai dengan prioritas nasional (UU No. 33 tahun 2004). DAK ini penggunaannya diatur oleh Pemerintah Pusat dan hanya digunakan untuk kegiatan pendidikan, kesehatan, keluarga berencana, infrastruktur jalan dan jembatan, infrastruktur irigasi, 
infrastruktur air minum dan sanitasi, prasarana pemerintah daerah, lingkungan hidup, kehutanan, sarana prasarana pedesaan, perdagangan, pertanian serta perikanan dan kelautan yang semuanya itu termasuk dalam komponen belanja modal. Oleh karena itu, selain pertumbuhan ekonomi, SiLPA, PAD dan DAU, DAK memiliki pengaruh terhadap anggaran belanja modal, karena DAK ini cenderung akan menambah aset tetap yang dimiliki oleh pemerintah guna meningkatkan pelayanan publik.

Hasil penelitian yang dilakukan oleh Situngkir (2009) menunjukkan bahwa secara simultan pertumbuhan ekonomi, PAD, DAU dan DAK berpengaruh signifikan terhadap anggaran belanja modal. Secara parsial hanya variabel PAD, DAU dan DAK yang berpengaruh siginifikan terhadap anggaran belanja modal. Selain itu, hasil penelitian yang dilakukan oleh Romario (2012) berdasarkan uji F dapat disimpulkan bahwa variabel pendapatan asli daerah, dana alokasi umum, dan dana bagi hasil secara simultan berpengaruh signifikan terhadap pengalokasian anggaran belanja modal.

Berdasarkan penjelasan diatas, maka tujuan dari Penelitian yang akan dilakukan, yaitu : (1) Untuk menganalisis dan mengetahui Pengaruh Pendapatan Transfer terhadap Belanja Modal di Kabupaten Mamberamo Tengah; (2) Untuk menganalisis dan mengetahui Pengaruh Sisa Lebih Pembiayaan Anggaran (SiLPA) Terhadap Belanja Modal di Kabupaten Mamberamo Tengah.

Istilah "Governance" menunjukkan suatu proses di mana rakyat bisa mengatur ekonominya, institusi dan sumber-sumber sosial dan politiknya tidak hanya dipergunakan untuk pembangunan, tetapi juga untuk menciptakan kohesi, integrasi, dan untuk kesejahteraan rakyat. Dengan demikian, bahwa kemampuan suatu negara mencapai tujuan negara sangat tergantung pada kualitas tata kepemerintahan di mana pemerintah melakukan interaksi dengan sektor swasta dan masyarakat (Thoha; 2000, 12).

Sedangkan United Nations Development Programme (UNDP) mendefinisikan governance sebagai "the exercise of political, economic, and administrative authority to manage a nation's affair at all levels". Menurut definisi ini, governance mempunyai tiga kaki (three legs), yaitu economic, political, dan administrative. Economics governance meliputi proses-proses pembuatan keputusan (decisionmaking processes) yang memfasilitasi aktivitas ekonomi di dalam negeri dan interaksi diantara penyelenggara ekonomi. Economic governance mempunyai implikasi terhadap equity, property dan quality of life. Political governance adalah proses-proses pembuatan keputusan untuk formulasi kebijakan, sedangkan 
administrative governance adalah sistem implementasi proses kebijakan. Oleh karena itu institusi dari governance meliputi tiga domain, yaitu state (negara atau pemerintahan), private sector (sektor swasta atau dunia usaha), dan society (masyarakat), yang saling berinteraksi dan menjalankan fungsinya masing-masing (LAN, $2000: 5$ ).

Anggaran merupakan pernyataan mengenai estimasi kinerja yang hendak dicapai selama periode waktu tertentu yang dinyatakan dalam ukuran finansial, sedangkan penganggaran adalah proses atau metode untuk mempersiapkan suatu anggaran (Mardiasmo, 2002).

Menurut Halim (2004; 141). "Dana Alokasi Umum adalah dana yang berasal dari Anggaran Pendapatan Belanja Negara (APBN) yang dialokasikan dengan tujuan pemerataan kemampuan keuangan antar daerah untuk membiayai kebutuhan pengeluaraannya dalam rangka pelaksanaan desentralisasi."

Otonomi khusus adalah kewenangan khusus yang diberikan kepada daerah 'tertentu' untuk mengatur dan mengurus kepentingan masyarakat setempat menurut prakarsa sendiri tetapi sesuai dengan hak dan aspirasi masyarakat di daerah tersebut.

Otonomi Khusus bagi Provinsi Papua diberikan oleh Negara Republik Indonesia melalui Undang-undang Nomor 21 Tahun 2001 (Lembaran Negara Tahun 2001 No. 135 dan Tambahan Lembaran Negara No. 4151) yang telah diubah dengan Perpu No. 1 Tahun 2008 (LN Tahun 2008 No. 57 dan TLN No. 4843). UU 21/2001 yang terdiri dari 79 pasal ini mengatur kewenangankewenangan Provinsi Papua dalam menjalankan Otonomi Khusus. Selain hal-hal yang diatur secara khusus dalam UU ini, Provinsi Papua masih tetap menggunakan UU tentang Pemerintahan Daerah yang berlaku secara umum bagi seluruh daerah di Indonesia.

Dana Bagi Hasil (DBH) adalah dana yang bersumber dari pendapatan APBN yang dialokasikan kepada daerah dengan memperhatikan potensi daerah penghasil berdasarkan angka persentase tertentu untuk mendanai kebutuhan daerah dalam rangka pelaksanaan desentralisasi. Dana Bagi Hasil (DBH) itu sendiri terdiri dari DBH Pajak dan DBH Sumber Daya Alam (SDA). Yang akan penulis jelaskan disini adalah Dana Bagi Hasil Pajak.

Perlu penulis sampaikan juga dasar hukum dari $\mathrm{DBH}$ yaitu : UU No. 12 Tahun 1985 yang telah diubah menjadi UU No. 12 Tahun 1994 tentang Pajak Bumi dan Bangunan; UU No. 17 Tahun 2000 tentang Perubahan Ketiga Atas UU No. 7 Tahun 1983 tentang Pajak Penghasilan; UU No. 11 Tahun 1995 yang telah diubah menjadi UU No. 39 Tahun 2007 tentang Cukai; UU No. 33 Tahun 
2004 tentang Perimbangan Keuangan Antara Pemerintah Pusat dan Pemerintahan Daerah; PP No. 55 Tahun 2005 tentang Dana Perimbangan; PP No. 58 Tahun 2005 tentang Pengelolaan Keuangan Daerah.

DBH Pajak berasal dari Penerimaan Negara atas Penerimaan Pajak Penghasilan (PPh) Wajib Pajak Badan dan Orang Pribadi Dalam Negeri atas PPh menurut Pasal 25 dan Pasal 29 Undang-Undang Pajak Penghasilan (UU PPh) serta PPh atas Pemungutan/Pemotongan Penghasilan Wajib Pajak menurut Pasal 21 UU PPh.

Dalam hal penganggaran tentunya bisa terjadi selisih antara pendapatan dan belanja daerah penyebabnya bisa sangat beragam, tetapi surplus atau defisit daerah yang timbul tersebut tentunya perlu disikapi oleh daerah dengan kebijakan Pembiayaan Daerah. Bila terjadi surplus maka daerah harus menganggarkan untuk pengeluaran pembiayaan tertentu semisal untuk investasi atau dapat juga dengan mengoptimalisasi dana tersebut untuk mendanai belanja kegiatan yang telah direncanakan. Akan tetapi bila terjadi defisit maka daerah perlu mencari alternatif pembiayaan yang bisa berupa pinjaman daerah, penggunaan SiLPA atau melakukan penghematan anggaran dengan melakukan penyisiran kegiatan yang tidak perlu dilaksanakan atau ditunda pelaksanannya.

Belanja Modal adalah pengeluaran anggaran untuk perolehan aset tetap dan aset lainnya yang memberi manfaat lebih dari satu periode akuntansi. Belanja modal meliputi antara lain belanja modal untuk perolehan tanah, gedung dan bangunan, peralatan dan aset tak berwujud (PP Nomor 24 Tahun 2005). Dengan kata lain belanja modal dilakukan dalam rangka pembentukan modal yang sifatnya menambah aset tetap/inventaris yang memberikan manfaat lebih dari satu periode akuntansi, termasuk di dalamnya adalah pengeluaran untuk biaya pemeliharaan yang sifatnya mempertahankan atau menambah masa manfaat, meningkatkan kapasitas dan kualitas aset.

Penelitan ini merupakan suatu kajian yang berangkat dari berbagai konsep teori dan kajian penelitian yang mendahuluinya. Dimana Anggaran Daerah merupakan rencana keuangan yang menjadi dasar dalam pelaksanaan pelayanan publik dan merupakan output pengalokasian sumberdaya. Keterbatasan sumber daya adalah pangkal masalah utama dalam pengalokasian anggaran daerah. Pemerintah Daerah (Pemda) mengalokasikan dana dalam bentuk anggaran belanja modal dalam Anggaran Pendapatan Belanja Daerah (APBD) untuk menambah asset tetap. Alokasi Belanja Modal ini didasarkan pada kebutuhan daerah akan sarana dan prasarana, baik untuk kelancaran pelaksanaan tugas pemerintahan maupun untuk kualitas pelayanan publik. Besarnya belanja modal 
yang dialokasikan pemerintah daerah dalam APBD tentu sangat dipengaruhi oleh posisi keuangan pada daerah tersebut. Posisi keuangansuatu daerah dapat dilihat dari besarnya Pertumbuhan Ekonomi, Pendapatan Asli Daerah (PAD) dan Dana Alokasi Umum (DAU) pada daerah tersebut. Untuk menyederhanakan alur pemikiran tersebut, maka kerangka konseptual dalam penelitian ini dapat digambarkan sebagai berikut :

\section{Gambar 1.2 Gambaran Alur pengaruh Dana Tranfer dan SiLPA Terhadap Belanja Modal}

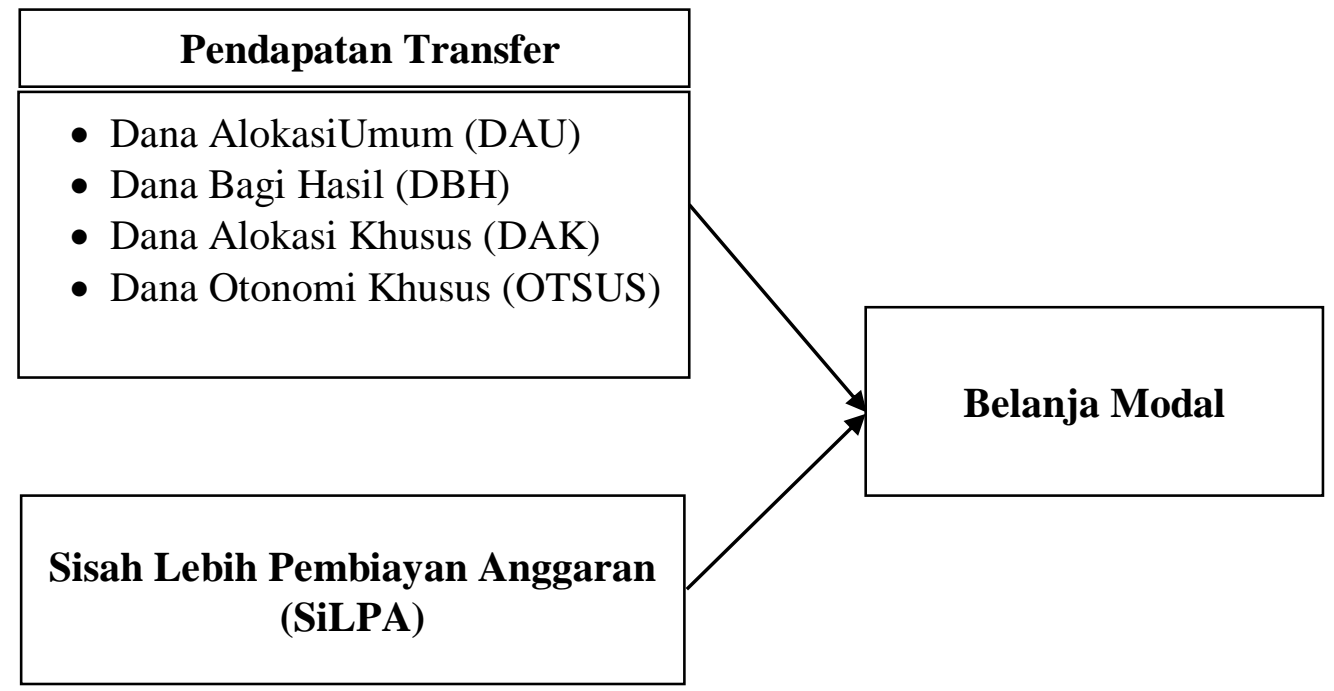

Sumber: Berbagai Sumber, 2016

\section{METODE PENELITIAN}

Data yang dikumpulkan selanjutnya diolah dan kemudian dianalisis secara kualitatif (deskriptif) dan kuantitatif. Teknik analisis dalam penelitian ini terdiri dari analisis deskriptif dan analisis statistik. Kedua teknik ini digunakan untuk mendapatkan hasil yang optimal. Sementara itu juga peneliti mengunakan pendekatan jenis data kuantitatif dan kualitatif. Pendekatan Kuantitatif digunakan dalam menganalisis pendapatan hususnya sumber dana DAU, DAK, DBH, dan SILPA sedangkan belanja daerah di khususnya belanja modal yang mana tipe penelitian ini merupakan timeseries. Sedangkan pendekatan kualitatif digunakan dalam menganalisis sifatnya deskriptif analitik terhadap Data yang diperoleh seperti hasil pengamatan, hasil pemotretan, analisis dokumen, catatan lapangan, disusun peneliti di lokasi penelitian, tidak dituangkan dalam bentuk angka-angka. Peneliti segera melakukan analisis data dengan memperkaya informasi, mencari 
hubungan, membandingkan, menemukan pola atas dasar data aslinya. Selanjutnya Analisis desktiptif digunakan untuk memberikan gambaran mengenai variabel penelitian. Statistik deskriptif yang digunakan antara lain; mean, median, minimum, maximum, dan standard deviation.

\section{HASIL DAN PEMBAHASAN}

\section{Pengaruh Pendapatan Transfer terhadap belanja Modal}

Belanja Modal sebagaimana dimaksud dalam pasal 50 huruf c Permendagri No 59 Tahun 2007 tentang perubahan Permendagri Nomor 13 Tahun 2006 Tentang pengelolaan Keuangan Daerah digunakan untuk pengeluaran yang dilakukan dalam rangka pengadaan aset tetap berwujud yang mempunyai nilai manfaat lebih dari 12 (dua belas) bulan untuk digunakan dalam kegiatan pemerintahan. Sedangkan menurut Pernyataan Standar Akuntansi Pemerintahan (PSAP) Nomor 2, Belanja Modal adalah pengeluaran anggaran untuk perolehan aset tetap dan aset lainnya yang memberi manfaat lebih dari satu periode akuntansi. Kabupaten Mamberamo Tengah merupakan salah satu daerah otonom baru (DOB) di Provinsi Papua, tuntutan ketersediaan modal dalam rangka penyelenggaraan pemerintah daerah dan pembangunan masyarakat merupakan fokus bagi Kabupaten Mamberamo Tengah.

Berdasarkan hasil dan pembahasan analisis data menunjukkan sumber Dana Bagi Hasil (DBH) merupakan sumber pendanaan yang sangat mempengaruhi secara positif dan dominan terhadap alokasi belanja modal dalam struktur APBD di Kabupaten Mamberamo Tengah. Dalam artian bahwa jika terjadi peningkatan penerimaan transfer Dana Bagi Hasil (DBH) dari Pihak Pusat maka akan meningkatkan alokasi belanja modal sebesar 99,9 persen, dukungan sumber dana ini memiliki Juklak/Juknis Tatacara Penggunaan Dana Bagi Hasil (DBH) di tingkat Kabupaten/Kota. Hal ini dapat memberikan suatu pengertian bahwa semakin tinggi eksploitasi sumber daya alam yang mendorong adanya penerimaan asli daerah dapat secara tidak langsung mampu memberikan efek kepada jumlah penerimaan transfer Dana Bagi Hasil $(\mathrm{DBH})$ dan mampu meningkatkan belanja modal daerah di Kabupaten Mamberamo Tengah. Hal ini didukung dengan Pada Tahun 2010 jumlah transfer Dana Bagi Hasil (DBH) bagi Kabupaten Mamberamo Tengah sebesar Rp.17,563,412,911,- dengan perkembangan yang terjadi maka pada tahun 2016 menerima transfer Dana Bagi Hasil (DBH) sebesar Rp.80,737,642,000,. Hasil ini sejalan dengan hasil penelitian yang dilakukan oleh I Nyoman Darmayasa, (2014) Dana Bagi Hasil (DBH) memiliki hubungan yang positif terhadap alokasi belanja modal pemerintah provinsi. Alokasi 
DBH dalam ABPD Provinsi ditentukan oleh kebijakan pemerintah provinsi. Dalam kurun waktu 2011-2013 DBH terbukti digunakan untuk membangun infrastruktur daerah, DBH merupakan faktor penentu alokasi Belanja Modal.

Secara kerangka penignkatan pendapatan asli daerah, peningkatan belanja modal yang ditujukan untuk menciptakan/mendukung ekspolitasi positif sumber daya alam mampu memberikan dampak tersendiri baik bagi pemerintah daerah maupun masyarakat. Pemerintah Daerah memiliki sejumlah penerimaan daerah yang mana mampu meingkatkan kemandirian fiskal daerah sedangkan masyarakat. mampu terlibat dalam upaya dan turut berproses dalam eksploitasi sumber daya alam. Secara kuantitatif ditemuai bahwa perubahan nilai rupiah belaja modal dengan $\mathrm{DBH}$ menjadi faktor utama dalam menentukan nilai pengaruh yang dominan dibandingkan sumber pendapatan transfer dan SilPA dalam penelitian ini. Namun jika cermati berdasarkan hasil pengamatan, bahwa peranan belanja yang mampu mendorong pembangunan di Kabupaten Mamberamo Tengah dalam kerangka peningkatan modal sektoral sebagai ujung tombak pembangunan ialah berasal dari sumber $\mathrm{DBH}$.

Tahun 2016 penerimaan DBH bukan pajak/sumber daya alam sebesar Rp.70 Miliar dengan komposisi bagi hasil dari kehutanan sebanyak Rp. 68 Milliar, sektor kehutanan sebanyak Rp.715 Juta, dan Dana Bagi Hasil dari Perikanan sebesar Rp.1,080 milliar. Secara intuitif diketahui bahwa penerimaan dari sumber dana bagi hasil secara proporsi dominan digunakan/dianggarkan untuk peningkatan, pengembangan, dan pemeliharaaan sarana dan prasarana produksi sektor-sektor unggulan terkait di Kabupaten Mamberamo Raya.

Sedangkan untuk Dana Alokasi Umum (DAU) memiliki pengaruh yang sangat kecil hanya 39,4 persen terhadap kapasitas belanja modal melalui alokasi belanja modal yang bersumber dari DAU pada penyusunan APBD di Kabupaten Mamberamo Tengah pada tahun 2010-2016. Dana Alokasi Umum (DAU) difungsikan sebagai Kebutuhan fiskal daerah merupakan kebutuhan pendanaan daerah untuk melaksanakan fungsi layanan dasar umum. Layanan dasar publik yang dimaksud antara lain penyediaan layanan kesehatan dan pendidikan, penyediaan infrastruktur, dan pengentasan masyarakat dari kemiskinan (Yani, 2008;144). Berdasarkan informasi yang cukup minim melalui dokumen APBD pada tahun 2013 belanja DAU dianggarakan untuk pembiayaan perkantoran, koordinasi, dan lain-lain. Kegiatan yang ditujukan untuk belanja modal masih terbatas pada pemeliharaan kendaraan operasional, pelepasan tanah adat.

Pada tahun 2016 berdasarkan potret belanja bahwa, Dana DAU dalam mendukung peningkatan belanja Modal Pemerintah Daerah Mamberamo Raya 
ialah, bantuan organisasi kemansyarkatan yakni bantuan pembangunan gereja bethel sebesar Rp. 5.100 Milliar, porsi alokasi belanja DAU di Kabupaten Mamberamo Raya difokuskan kepada program-program penyediaan jasa surat menyurat, rehablitasi sedang gedung pemerintah, dukungan terhadap pelaporan kinerja pemerintah daerah, pengadaan aplikasi surat menyurat, penyusunan peraturan daerah, dan Penyusunan APBD.

Dana Alokasi Khusus (DAK) diketahui memiliki tujuan pembangunan sebagai berikut: (1) Mendukung pencapaian prioritas nasional, termasuk program-program prioritas nasional yang bersifat lintas sektor/kewilayahan sesuai dengan kerangka pengeluaran jangka menengah (medium term expenditure framework) dan penganggaran berbasis kinerja (performance based budgeting); (2) Membantu daerah-daerah yang memiliki kemampuan keuangan relatif rendah dalam membiayai pelayanan publik dalam rangka pemerataan pelayanan dasar dan mendorong pencapaian SPM; (3) Meningkatkan kualitas perhitungan alokasi DAK, serta mempercepat penyusunan petunjuk teknis penggunaan DAK yang ditujukan untuk mendorong penyusunan Anggaran Pendapatan dan Belanja Daerah (APBD) yang efektif, efisien, dan tepat waktu; (4) Meningkatkan koordinasi pengelolaan DAK secara utuh dan terpadu di pusat dan daerah sehingga terwujud sinkronisasi kegiatan DAK dengan kegiatan lain yang didanai dari sumber-sumber pendanaan lainnya; (5) Meningkatkan penyediaan data-data teknis yang lebih akurat sebagai basis kebijakan kementerian dan lembaga dalam rangka meningkatkan keserasian dan menghindari duplikasi kegiatan antar bidang DAK; (6) Mendorong penggunaan kinerja pelaporan sebagai salah satu pertimbangan dalam penyusunan kriteria pengalokasian DAK.

Dana Otonomi Khusus (OTSUS) di Kabupaten Mamberamo Tengah secara perhitungan statistik diketahui positif mempengaruhi belanja modal. Walaupun secara pengaruh sangat kecil, namun kontribusi sumber dana OTSUS terhadap pembangunan sektor khususnya belanja modal memiliki andil yang cukup signifikan. Hal ini, terungkap pada tahun 2016 alokasi proporsi belanja modal yang bersumber dari Dana OTSUS antara lain: pembangunan gereja KOBAKMA, bantuan Lembaga Adat Masyarakat, Bantuan Pendidikan seacra wujud investasi Sumber Daya Manusia (SDM) pada jenjang pendidikan PAUD, SD, SMP, SMA, dan Perguruna Tinggi, Pembangunan Kesehatan baik tenaga kesehatan, fasilitas kesehatan, belanja modal kendaraan roda 4 bagi gereja 15 unit merek Triton.

Berdasarkan hasil perhitungan model Sumber Dana yang berasal dari transfer Dana Alokasi Khusus (DAK) Kabupaten Mamberamo Tengah memiliki pengaruh terhadap Belanja Modal sebesar 57 persen. Hal ini dapat dibuktikan 
dengan salah satu kasus bahwa pada tahun 2016 penggunaan DAK diarahkan kepada DAK reguler dimana membiayai Bidang Kesehatan dan KB, Bidang perumahan, Air Minum, dan Sanitasi, Bidang Kedaulatan Pangan, Lingkungan Hidup, Biang Transportasi, Bidang Perdagangan, DAK IPD, DAK Afirmasi yang dianggarkan yakni belanja modal Air Minum, Sanitasi, Infrastruktur, Jalan, dan Transportasi Perdesaan. Sedagkan untuk DAK Non Fisik digunakan untuk pembiayaan (1) Bantuan Operasional Penyelenggaraan PAUD, (2) Tambahan Penghasilan Guru, (3) Bantuan Operasional Kesehatan, (4) Jaminan Persalinan, (5) Bantuan Operasional KB. Dimana dnegan nilai pengaruh 57 persen hal ini dapat dibuktikan bahwa banyaknya kegiatan yang arahkan kepada penyediaan belanja modal pada bidang-bidang pembangunan yang mana merupakan perioritas pembangunan nasional di Indonesia.

\section{Pengaruh Positif SiLPA berpengaruh terhadap Belanja Modal}

SiLPA diketahui mamu memberikan pengertian yang beragam, menajdi wacana umum bahwa tingginya SilPA mampu memebrikan gambaran lemahnya efektifitas realisasi keuangan dan fisik dalam penyelenggaraan APBD, faktor lain yang mampu mendorong ialah keterlambatan penyusunan APBD juga memberikan warna tersendiri dalam peningkatan SiLPA di Tahun anggaran tertentu. Dalam penelitian ini bahwa, ingin diketahui apakah SiLPA digunakan dalam tahun berkutnya dalam kerangka peningkatan belanja modal. Berdasarkan hasil estimasi pengukuran bahwa diketahui pengaruh SiLPA terhadap Belanja Modal memiliki pengaruh yang positif. Berdasarkan hasil perhitungan model, diketahui bahwa SiLPA cukup besar mempengaruhi alokasi belanja modal selama 2010-2016 di Kabupaten Mamberamo Tengah, hal ini dibuktikan nilai 83,9 persen berpengaruh positif terhadap alokasi belanja modal.

Keberadaan SiLPA di Kabupaten Mamberamo Tengah ini diantaranya juga disumbang oleh penyerapan belanja modal yang rendah. Semakin besar SiLPA menunjukkan ketidakcermatan dalam penganggaran (perencanaan yang kurang baik) atau adanya kelemahan dalam pelaksanaan anggaran. Beberapa hal yang menyebabkan rendahnya penyerapan belanja modal adalah sebagai berikut: (a) Adanya kegiatan/proyek yang belum dapat didanai disebabkan oleh keterbatasan keuangan daerah; (b) Terjadi efisiensi dalam belanja, dimana kegiatan/proyek dalam belanja modal dapat diselesaikan dengan biaya lebih rendah dari pagu anggarannya; (c) Terdapat masalah pembebasan lahan dalam kegiatan pembangunan proyek infrastruktur pemerintah; (d) Ada masalah dalam proses pengadaan barang dan jasa; (e) Sisa waktu yang tersedia tidak mencukupi untuk 
menyelesaikan program/kegiatan belanja modal daerah; dan (e) Petunjuk teknis pelaksanaan DAK yang terlambat diterima daerah.

Beberapa kegiatan yang telah dilaksankan oleh Pemerintah Kabupaten Mamberamo Tengah Antara lain: dilakukan pembangunan rumah dinas, pengadaan kendaraan operasional, pelayanan transportasi udara, pembangunan gedung SD, dan penyertaan Modal kepada Badan Usaha Milik Daerah selain itu juga dana SilPA digunakan untuk pendatan dan validasi Asset Daerah. Hal ini membuktikan bahwa walaupun SiLPA tidak menjadi faktor yang dominan yang mempengaruhi belanja modal, namun secara perencanaan dan penganggaran kegiatan. SiLPA secara positif turut berkontribusi dalam peningkatan modal dan asset pemerintah daerah Kabupaten Mamberamo Tengah.

\section{KESIMPULAN DAN SARAN}

\section{Kesimpulan}

a. Hasil penelitian ini menghasilkan model yang dapat menjelaskan bahwa transfer pemerintah pusat melalui sumber dana DBH, DAU, DAK dan OTSUS memiliki pengaruh positif terhadap belanja modal. Sumber Dana Bagi Hasil (DBH) memiliki pengaruh yang dominan dibandingkan dengan sumber dana lainnya.

b. SiLPA berpengaruh positif terhadap belanja modal. Pemerintah Kabupaten Mamberamo Tengah menggunakan sumber SiLPA antara lain untuk pembangunan rumah dinas, pengadaan kendaraan operasional, pelayanan transportasi udara, pembangunan gedung SD, dan penyertaan modal.

\section{Saran}

a. Pemerintah Daerah Kabupaten Mamberamo Tengah perlu secara konsisten dalam penggunan alokasi $\mathrm{DBH}$ dalam rangka meningkatkan sektor pertambangan, kehutanan, dan perikanan. Sejalan dengan hal ini, dapat bersamaan menggali dan mengoptimal sektor lainnya dalam rangka adanya pemanfaatan potensi daerah. Selain itu juga kepatuhan dalam penggunaan masing-masing Sumber Dana perlu diperhatikan dalam penyusunan Anggaran pada tingkat SKPD.

b. Sumber Dana DAK menjadi salah satu sumber dana perimbangan yang cukup dominan mempengaruhi belanja modal pemerintah daerah. Berdasarkan hal tersebut memiliki implikasi penganggaran bahwa pemerintah pusat perlu menaikkan porsi transfer DAK yang secara positif mampu mendorong mewujudkan pelayanan publik di Kabupaten Mamberamo Tengah. 
c. Pemerintah Daerah diharapkan melakukan restrukturisasi sumber daya manusia (SDM) atau melakukan kalkulasi kebutuhan DAU. Dalam rangka penghematan belanja tidak langsung dan lebih mengutamakan alokasi kepada belanja modal langsung yang memiliki pengaruh positif terhadap pelayanan publik.

d. Perlu adanya kebijaksanaan dalam pengelolaan Sumber Dana yang berasal dari SiLPA, hal ini dapat diwujudkan dalam penyusunan PERBUB terkait kewajiban lainnya yang perlu dibiayai pada tahun anggaran berjalan. Sehingga pengunaan SiLPA dalam rangka peningkatan belanja modal yang mendukung pelaksanaan pembangunan daerah dapat dimanfaatkan secara baik dan akuntabel.

e. Pemerintah Daerah melalui perlu melakukan review terhadap peluangpeluang setiap sumber daya keuangan dari pendapatan transfer untuk di anggarkan sebijak-bijaknya dalam upaya meningkatkan pengadaan infrastruktur, sarana dan prasarana publik.

\section{DAFTAR PUSTAKA}

Abdullah, Syukriy dan Halim Abdul, 2004. "Pengaruh Dana Alokasi Umum (DAU) dan Pendapatan Asli Daerah (PAD) terhadap Belanja Pemerintah Daerah : Studi Kasus Kabupaten/Kota di Jawa dan Bali”, Proceeding Simposium Nasional Akuntansi VI, 16-17 Oktober 2003, Surabaya.

Abdullah, Syukriy, 2004. "Perilaku Oportunistik Legislatif dalam Penganggaran Daerah: Pendekatan Principal-Agent Theory. Makalah disajikan pada Seminar Antarbangsa di Universitas Bengkulu. Bengkulu, 4-5 Oktober 2004.

Bappenas, 2003. Peta Kemampuan Keuangan Propinsi dalam Era Otonomi Daerah : Tinjauan Atas Kinerja PAD dan Upaya yang dilakukan Daerah. Direktorat Jenderal Pengembangan Otonomi Daerah, Jakarta.

Boediono, 1985. Pengantar Ilmu Ekonomi No. 4 BPFE. Yogyakarta.

Darwanto dan Yulia Yustikasari 2007. " Pengaruh Pertumbuhan Ekonomi, Pendapatan Asli Daerah, Dana Alokasi Umum terhadap Pengalokasian Anggaran Belanja Modal : Studi Kasus Kabupaten/Kota di Jawa dan Bali”, Simposium Nasional Akuntansi X. 26-28 Juli 2007.

Ghozali, Imam. 2005. Aplikasi Analisis Multivariate dengan Program SPSS. Badan Penerbit Universitas Diponegoro, Semarang.

Halim, Abdul 2004, Akuntansi Keuangan Daerah, Edisi Revisi, Salemba Empat, Jakarta

Halim, Abdul \& Syukriy Abdullah 2006, Hubungan dan Masalah keagenan di Pemerintahan Daerah: Sebuah Peluang Penelitian Anggaran dan Akuntansi Jurnal Akuntansi Pemerintah 2 (1) : 53-64

Hari Priyo Adi, 2007, "Hubungan Antara Pertumbuhan Ekonomi, Belanja Pembangunan, dan Pendapatan Asliu Daerah (PAD): Studi Kasus 
Kabupaten/Kota Se Jawa-Bali”, Simposium Nasional Akuntansi IX, Padang.

Mardiasmo, 2002, Otonomi dan Manajemen Keuangan Daerah, Andi, Yogyakarta.

Nugroho, Bhuono, Agung. 2005. Strategi Jitu Memilih Metode Statistik Peneltian dengan SPSS, Edisi I. Andi. Yogyakarta.

Keefer, Philip and Khemani, Democracy, Publik Expenditures, and The Poor, 2003, Work Bank Policy Research Working Paper 3164.

Rubin, Irene 1993. The Politics of Publik Budgeting: Getting and Spending, Borowing and Balancing. Second Edition. Chatam, NJ: Chatman House Publishers, Inc.

Kuncoro, Mudrajat, 2004, Otonomi dan Pembangunan Daerah; Reformasi Perencanaan, Strategi dan Peluang. Penerbit Erlangga. Jakarta.

Keban, Yeremias T., 2000, Good Governance dan Capacity Building sebagai Indikator Utama dan Fokus Penilaian Kinerja Pemerintahan, dalam Jurnal Perencanaan Pembangunan, Jakarta.Lembaga Administrasi Negara, 2000, Akuntabilitas dan Good Governance, Modul Sosialisasi Sistem Akuntabilitas Kinerja Instansi Pemerintah (AKIP), Jakarta.

Samuels, David 2000. Fiskalhorizontal accountability? Toward theory of budgetary "checks and balances" In presidential systems. University of Minnesota, Working paper presented at the Conference on Horizontal Accountability In New Democracies, University of Notre Dame, May.

Samuelson, Paul 2004. Ilmu Makro Ekonomi, Edisi 17 (terjemahan). Penerbit Media Global Edukasi. Jakarta.

Siagian Monika, 2008, " Pengaruh Dana Alokasi Umum (DAU), Pendapatan Asli Daerah (PAD) dan pendapatan lain-lain yang dianggap sah terhadap belanja Pemerintah Daerah : Studi Kasus Kabupaten/Kota di Propinsi Sumatera Utara.

Saragih, Juli Panglima, 2003. Desentralisasi Fiskal dan Keuangan Daerah dalam Otonomi, Penerbit Ghalia Indonesia, Jakarta.

Sugiono, 2005. Metode Penelitian Bisnis Cetakan Kedelapa, Alfabeta, Bandung.

Thoha, Miftah, 2000, Peranan Administrasi Publik dalam Mewujudkan Tata Kepemerintahan yang Baik, Disampaikan pada Pembukaan Kuliah Program Pasca Sarjana, UGM, Yogyakarta.

Van, Hogen, 2005, Political Economy of Fiskallnstitutions, Discussion paper 149, Governance and efficiency of Economic System, GESY.

Keputusan Menteri Dalam Negeri Nomor 29 Tahun 2002 tentang Pedoman Pengurusan, Pertanggungjawaban dan Pengawasan Keuangan Daerah, Serta Tata Cara Penyusunan Anggaran Pendapatan dan Belanja Daerah, Pelaksanaan Tata Usaha Keuangan Daerah dan Penyusunan Perhitungan Anggaran Pendapatan dan Belanja Daerah.

, Peraturan Menteri Dalam Negeri No. 13 Tahun 2006, Tentang Pedoman Pengelolaan Keuangan Daerah.

-----, Undang-Undang Republik Indonesia Nomor 22 Tahun 1999 tentang Pemerintah Daerah, Departemen Komunikasi dan Informatika, Jakarta.

Perimbangan Keuangan antara Pemerintah Pusat dan Daerah, Departemen Komunikasi dan Informatika, Jakarta. 
Jurnal Keuda Vol. 2 No. 2

ISSN 2477-7838

Undang-Undang Keuangan Negara Tahun 2003 tentang Pemerintah Daerah, Departemen Komunikasi dan Informatika, Jakarta. 